HELMINTHOLOGIA, 53, 1: 55 - 61, 2016

\title{
Preference for microhabitat by Monogenea on the gills of the south american catfish Rhamdia quelen at different stocking densities under laboratory conditions
}

\author{
J. A. DEBORTOLI', A. C. F. LACERDA², T. R. LISBOA ${ }^{1}$, M. L. MARTINS' ${ }^{1}$
}

${ }^{1}$ AQUOS - Aquatic Organisms Health Laboratory, Aquaculture Department, CCA, Federal University of Santa Catarina, Rod. Admar Gonzaga, 1346, 88040-900, Florianópolis, SC, Brazil; 'Federal University of Paraíba, Department of Systematics and Ecology, CCEN,, Castelo Branco, 58051-900, João Pessoa, PB, Brazil, E-mail: acflacerda@dse.ufpb.br

Article info

Received October 7, 2013 Accepted October 21, 2015

\begin{abstract}
Summary
This study aimed to verify preferences for microhabitat by the monogeneans on the gills of the south american catfish, Rhamdia quelen (Quoy \& Gaimard, 1824), at different stocking densities under controlled laboratory conditions. Three stocking densities were used: 14, 28 and 42 fish per tank (50 $\mathrm{L})$ and the fish were sampled initially, at day 5 and 10 of the experiment. Aphanoblastella mastigatus (Suriano, 1986) was noted as the most abundant species at all stocking densities, except for the initial collection day. The gill arches I and II were the most parasitized, showing the highest mean abundance in the dorsal region, at the highest density. The pattern of microhabitat preference of A. mastigatus for outer regions of the gills of the host was independent of the stocking density and collection day. Higher prevalence and abundance of Scleroductus sp. at the initial collection reflected the parasitic infection of the fish at the farm from where the fish were taken. The abundance of Scleroductus sp. decreased along the experiment, and no preference for gill arches was recorded for the species, probably due to the low abundance of this parasite on the gills.
\end{abstract}

Keywords: fish; parasitology; monogenean; ectoparasites; ecology

\section{Introduction}

In Southern Brazil, the south american catfish locally known as "jundiá" (Rhamdia quelen) is one of the most cultivated fish species, along with the Nile tilapia Oreochromis niloticus (Linnaeus, 1758); common carp Cyprinus carpio Linnaeus, 1758; grass carp Ctenopharyngodon idella (Valenciennes, 1844); silver carp Hypophtalmichthys molitrix (Valenciennes, 1844); bighead carp Hypophthalmichthys nobilis (Richardson, 1845) and rainbow trout Oncorhynchus mykiss (Walbaum, 1792). South american catfish production represented $1.8 \%$ of Brazilian fish production in 2010 and it has increased to $2.4 \%$ in 2011, responsible for 215 tons more than the anterior year (Silveira \& Silva, 2011). In order to obtain maximum production at low costs, frequently the highest quantity of fish per tank as possible is used, and fish frequently cul- tivated under high densities that culminate in disease outbreaks. Monogeneans are responsible for major diseases outbreaks in aquaculture, causing great mortality in intensive fish farming (Paperna et al. 1984; Thoney \& Hargis, 1991; Moraes \& Martins, 2004; Tu et al., 2015).

Monogeneans are generally host specific; one species of parasite occurs in a single species or closely related species of hosts (Thatcher et al., 2006). In Brazil, a considerable number of studies on monogeneans parasites of fish were performed (Kohn \& Cohen, 1998; Takemoto et al., 2009; Jerônimo et al., 2011a; Kritsky et al., 2013; Marchiori et al., 2013), but few studies focused on their possible microhabitat preference (Oliva \& Luque, 1998; Jerônimo et al., 2013).

Some hypothesis have been thought and tested to explain the choice of the parasite for a microhabitat. The suggested explana- 
tions include the heterogeneous water flow in the gills (El Hafidi et al., 1998; Rubio-Godoy \& Tinsley, 2002; Rubio-Godoy, 2008; Jeannette et al., 2010; Soler-Jiménez \& Fajer-Ávila, 2012), parasite migration (Arme \& Halton, 1972; Buchmann \& Bresciani, 1997; Rubio-Godoy \& Tinsley, 2002), intraspecific interaction of parasites with aggregation to facilitate the reproduction (Rohde, 1979; Kadlec et al., 2003; Raymond et al., 2006; Jeannette et al., 2010), inhibition of a possible hybridization between species (Rubio-Godoy, 2008; Soler-Jiménez \& Fajer-Ávila, 2012) and differences in the area or size of the gills (Buchmann, 1989; Rubio-Godoy, 2008; Soler-Jiménez \& Fajer-Ávila, 2012).

The selection of microhabitats on the sites of infection of monogeneans does not show evident pattern. Therefore, the preference for microhabitat is a result of a complex process where several possibilities can be considered (Gutiérrez \& Martorelli, 1999). This assay investigated the influence of the stocking density of fish on the monogenean distribution on the gills of the south american catfish under laboratory conditions.

\section{Material and Methods}

Fish used in the assay were albino south american of the same spawn, obtained from a disease-free stock of the fish farming Khran, in Pomerode, Santa Catarina State, Brazil. They were naturally parasitized by monogeneans. Fish presented $21.24 \pm$ $6.91 \mathrm{~g}$ weight and $12.8 \pm 61.44 \mathrm{~cm}$ of total length. They were distributed into 18 aquaria of $50 \mathrm{~L}$ capacity with individual biological filters and aeration. Fish were fed twice a day "ad libitum" with commercial diet of $42 \%$ crude protein, and divided at the following stocking densities (treatments): 14, 28 fish and 42 fish per tank $(50 \mathrm{~L})$, with six replicates of each treatment. The tested stocking densities were similar to Pouey et al. (2011). During the assay, the following water variables were monitored: $\mathrm{pH} 8.2 \pm 0.5$ (measured with Quimis ${ }^{\circledR}$ equipment), dissolved oxygen $7.6 \pm 0.5 \mathrm{mg} \cdot \mathrm{L}^{-1}$ (measured at every 3 days with a multiparameter HANNA ${ }^{\circledR}$ ), and water temperature $28.0 \pm 1.0^{\circ} \mathrm{C}$ (measured with a multiparamter HANNA $^{\circledR}$ ) controlled with termostates and daily monitored.

At the beginning of the assay, 18 fish were examined for parasites. In addition, parasitological evaluation of fish occurred at day five and at day ten of the assay (six fish of three replicates of each treatment were collected, a total of 18). These experimental units were then discharged.

Fish were killed by a lethal dose of eugenol dissolved in water (approved by the Ethic Committee CEUA/UFSC-PP00756). Their gills were cutted out from the fish (Eiras et al., 2006), the gill arches were separated according to the right and left side, and numbered from the outer to inner region of the operculum as arches I, II, III and IV. The arches were separated in three sectors: ventral, me-

Table 1. Prevalence (\%), mean and standard deviation of intensity and abundance of Scleroductus sp. and A. mastigatus in R. quelen at different collection days and stocking density. Mean intensities and mean abundances with the same letters did not differ significantly; mean intensities and mean abundances with different letters differ significantly $(p<0.05)$

\begin{tabular}{|c|c|c|c|c|}
\hline \multirow[b]{2}{*}{ Density } & \multicolumn{4}{|c|}{ Scleroductus sp. } \\
\hline & Collection & Prevalence & Mean intensity & Mean abundance \\
\hline \multirow{2}{*}{14 fish per tank } & Initial & 66.7 & $4.33 \pm 6.34^{a}$ & $2.89 \pm 5.52^{\mathrm{a}}$ \\
\hline & Day 5 & 33.3 & $2.17 \pm 1.17^{\mathrm{a}}$ & $0.72 \pm 1.23^{b}$ \\
\hline \multirow{3}{*}{28 fish per tank } & Initial & 66.7 & $4.33 \pm 6.34^{\mathrm{a}}$ & $2.89 \pm 5.52^{\mathrm{a}}$ \\
\hline & Day 5 & 44.4 & $2.63 \pm 1.77^{\mathrm{a}}$ & $1.17 \pm 1.76^{a}$ \\
\hline & Day 10 & 60.0 & $11.33 \pm 17.56^{a}$ & $6.80 \pm 14.34^{a}$ \\
\hline \multirow{4}{*}{42 fish per tank } & Initial & 66.7 & $4.33 \pm 6.34^{a}$ & $2.89 \pm 5.52^{\mathrm{a}}$ \\
\hline & Day 5 & 38.9 & $2.14 \pm 2.19^{a}$ & $0.83 \pm 1.69^{b}$ \\
\hline & Day 10 & 33.3 & $2.17 \pm 1.17^{a}$ & $0.72 \pm 1.23^{b}$ \\
\hline & \multicolumn{4}{|c|}{ Aphanoblastella mastigatus } \\
\hline \multirow{2}{*}{14 fish per tank } & Initial & 61.1 & $4.18 \pm 5.23^{\mathrm{Aa}}$ & $2.56 \pm 4.53^{\mathrm{Aa}}$ \\
\hline & Day 5 & 72.2 & $3.62 \pm 1.85^{\mathrm{Aa}}$ & $2.61 \pm 2.28^{\mathrm{Aa}}$ \\
\hline \multirow{3}{*}{28 fish per tank } & Initial & 61.1 & $4.18 \pm 5.23^{\mathrm{Aa}}$ & $2.56 \pm 4.53^{\mathrm{Aa}}$ \\
\hline & Day 5 & 83.3 & $3.07 \pm 2.25^{\mathrm{Aa}}$ & $2.56 \pm 2.36^{\mathrm{Ab}}$ \\
\hline & Day 10 & 100.0 & $9.50 \pm 3.57^{\mathrm{Bb}}$ & $9.50 \pm 3.57^{\mathrm{Bc}}$ \\
\hline \multirow{3}{*}{42 fish per tank } & Initial & 61.1 & $4.18 \pm 5.23^{\mathrm{Aa}}$ & $2.56 \pm 4.53^{\mathrm{Aa}}$ \\
\hline & Day 5 & 83.3 & $3.13 \pm 2.17^{\mathrm{Aa}}$ & $2.61 \pm 2.30^{\mathrm{Aa}}$ \\
\hline & Day 10 & 100.00 & $4.72 \pm 7.31^{\mathrm{ca}}$ & $4.72 \pm 7.31^{\mathrm{Ca}}$ \\
\hline
\end{tabular}


A

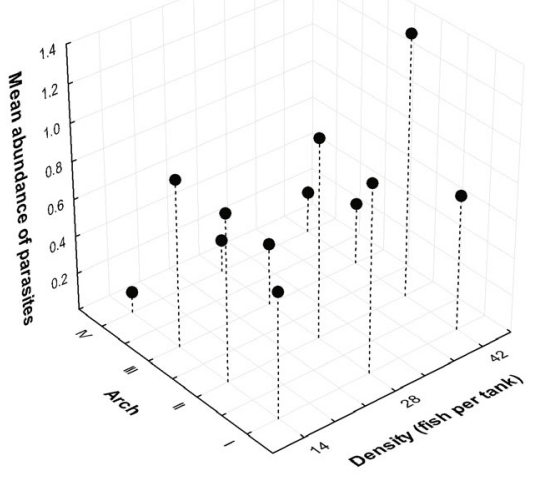

B

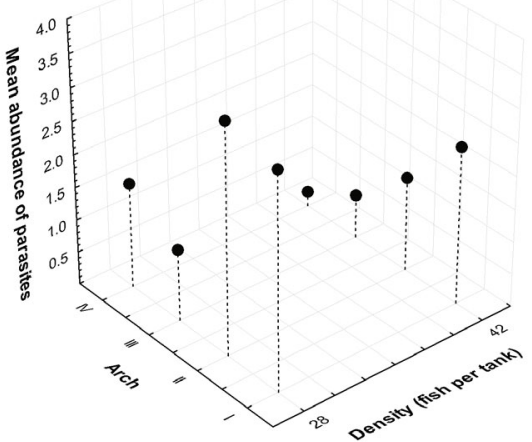

C

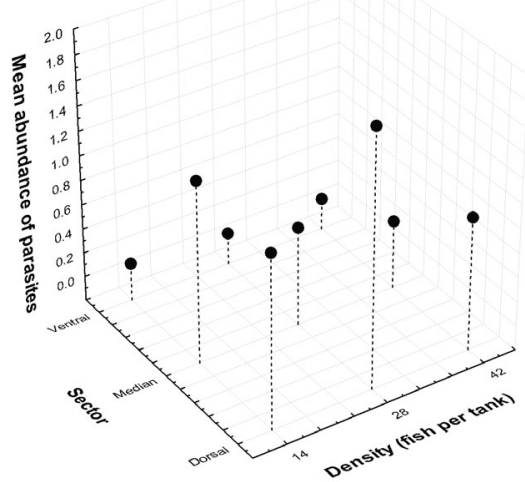

D

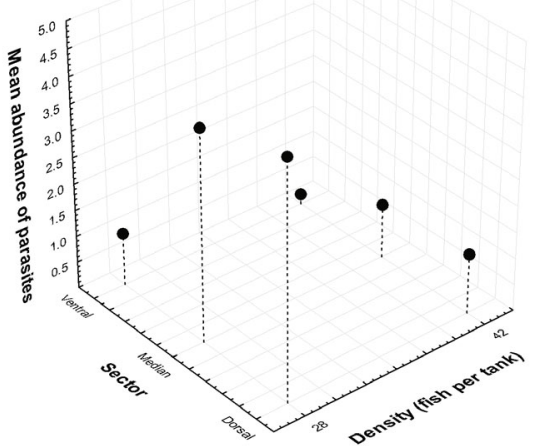

Fig. 1. Mean abundance of the parasite Aphanoblastella mastigatus on Rhamdia quelen, comparing the gill arches and stocking densities at day 5 (A) and day 10 (B) of the experiment, and comparing the gill sectors and stocking densities at day 5 (C) and day 10 (D) of the experiment

dium and dorsal according to Dzika (1999). After the collection, the gills were bathed in hot water $\left(55^{\circ} \mathrm{C}\right)$ for parasite release and fixed in alcohol 70 \% (Jerônimo et al., 2011b).

The parasites were mounted in Hoyer's medium and identified according to Kritsky et al. (1995) and Suriano (1986). Prevalence, mean intensity and mean abundance were calculated according to Bush et al. (1997).

Differences on parasitism between the right and left sides of the gills were evaluated using the Mann-Whitney's U test. To compare the number of parasites between different gill arches, gill sectors and collection days the Kruskal-Wallis test was used.

\section{Results}

Two species of monogeneans were identified parasitizing the gills: Scleroductus sp. (Gyrodactylidae) and Aphanoblastella mastigatus Suriano, 1986 (Dactylogyridae).

Fish maintained at the lowest density presented high number of the protozoan Ichthyophthirius multifilis (Fouquet, 1876) and necrosis foci on the fins and tail caused by bacteria. At day 10, two experimental units were lost at the density 14 fish per tank and one at the density fish per tank.

\section{Scleroductus sp.}

In total, 101 specimens of Scleroductus sp. were collected at day 5 , and 133 at day 10 . In relation to left and right side of the gills, there was no significant difference on the abundance of parasites found. Higher abundance and prevalence of Scleroductus sp. were observed at the initial sampling and in fish maintained at 28 fish per tank at day 10 (Table 1). Fish maintained at 14 fish per tank showed the highest mean abundance of monogeneans at the initial sampling when compared to day 5 . Considering all collection days, neither mean intensity, mean abundance nor prevalence of Scleroductus sp. showed differences between gill arches, gill sectors, stocking densities and collection days (Fig. 2).

\section{Aphanoblastella mastigatus}

In total, 186 specimens of $A$. mastigatus were collected at day 5 , and 228 at day 10. No significant difference was observed in the mean intensity and abundance among the stocking densities at day 5 (Table 1). The highest mean intensity and abundance were observed at day 10 in fish maintained at 28 fish per tank, followed by those at 42 fish per tank and initial collection. In fish maintained at 28 fish per tank and 42 fish per tank, the prevalence increased along the experimental period reaching $100 \%$ at day 10 .

On the initial collection, no preference for gill arches and sec- 
Table 2. Results of Mann-Whitney's $U$ test between the abundance of Scleroductus sp. and $A$. mastigatus on the gills of $R$. quelen, at three stocking densities, at diferent collection day. *Significant values $(P \leq 0.05)$

\begin{tabular}{cccc}
\hline \multicolumn{2}{c}{ Scleroductus sp. $\times$ A. mastigatus } & \multicolumn{2}{c}{ Mann-Whitney } \\
\hline Density & Collection & U & P \\
\hline \multirow{3}{*}{ 14 fish per tank } & Initial & 152.00 & 0.734 \\
\hline \multirow{2}{*}{ 28 fish per tank } & Day 5 & 81.00 & $0.007^{*}$ \\
& Day 5 & 95.00 & $0.029^{*}$ \\
& Day 10 & 20.50 & $0.025^{*}$ \\
\hline \multirow{2}{*}{42 fish per tank } & Day 5 & 73.50 & $0.004^{*}$ \\
& Day 10 & 38.00 & $0.001^{*}$ \\
\hline
\end{tabular}

tors were observed. At day 5 , fish maintained at 14 fish per tank showed preference for the gill arches II and III ( $p=0.035)$. Aphanoblastella mastigatus showed preference for the first gill arches in fish maintained at 28 fish per tank $(p=0.012)$. The mean abundance was higher in the gill arches I and II in fish maintained at 42 fish per tank $(p=0.001)$.

Aphanoblastella mastigatus showed preference for the dorsal and medium sectors $(50.00 \%)$ when compared to the ventral sector $(11.11 \%)$ in fish maintained at 14 fish per tank. In fish maintained at 28 fish per tank and 42 fish per tank the dorsal and medium sectors presented the highest abundance, respectively, at days 5 and 10 (Fig. 1).

\section{Scleroductus sp. versus Aphanoblastella mastigatus}

There was significant difference between the abundance of Scleroductus sp. and $A$. mastigatus in all treatments and collection days, except for the initial collection. Higher abundance of $A$. mastigatus was observed in all treatments. After 10 days, there was a high mortality of fish maintained at the density of 14 fish per tank, and due to significant losses these tanks were excluded from the analyzes (Table 2).

\section{Discussion}

Parasitological indexes of Scleroductus sp. and A. mastigatus were compared to evaluate whether one of them presented relation to the stocking density, collection day and distribution on the gills. The monogenean $A$. mastigatus was found to be the most abundant in all stocking densities with exception of the initial collection day. It is suggested that the environmental conditions were responsible for the high number of this parasite species, once farmed fish from the inital collection day showed differences when compared to laboratory facilities. According to Moraes and
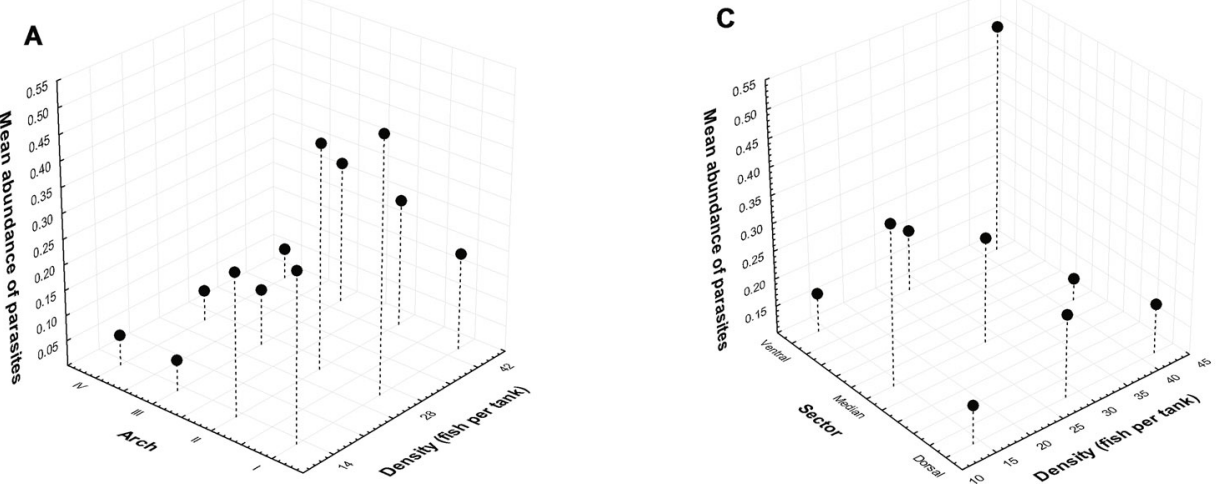

B

D
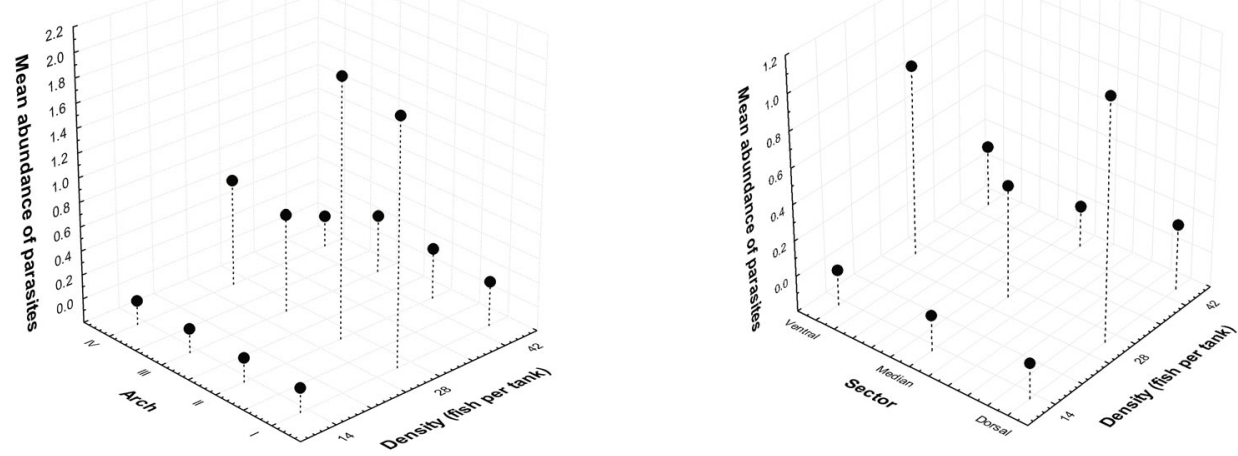

Fig. 2. Mean abundance of the parasite Scleroductus sp. on Rhamdia quelen, comparing the gill arches and stocking densities at day 5 (A) and day 10 (B) of the experiment, and comparing the gill sectors and stocking densities at day 5 (C) and day 10 (D) of the experiment 
Martins (2004) the water quality and farming conditions may favor proliferation. This study showed that the south american catfish maintained at high density were apparently more resistant when compared to the ones maintained at low density.

Ichthyophthiriasis and bacteriosis found in fish maintained at low density indicate that this enviroment was not favorable for the south american catfish under laboratory conditions, considering that all other variables were controlled except for the stocking density. Rhamdia quelen inhabits lakes and the bottom of rivers and prefers lentic waters (Baldisserotto \& Gomes, 2010). The fish maintained in laboratory are more exposed to stress, what favours spreading of the disease pathogens; in fish maintained at 42 fish per tank more protection could be observed with fish agglomeration, possibly favoring their wellfare.

Venancio et al. (2010) recognized Aphanoblastella sp. as a dominant parasite on the gills of the south american catfish in the Paraíba do Sul river, State of Rio de Janeiro. Regarding the preference for the left and right side of the gills, no significant differences were observed by other authors (lannacone \& Alvarino, 2012; Jeannette et al., 2010; Raymond et al., 2006; Rubio-Godoi, 2008; Backer et al., 2005), similar to the present assay, suggesting that the host is symetric and water flow must be the same through both sides.

Higher prevalence and abundance of Scleroductus sp. at the initial collection reflected the parasitic infection of the fish at the farm from where the fish were taken. The decrease in the abundance of Scleroductus sp. was observed along the experiment, while for $A$. mastigatus an increase in prevalence, mean intensity and mean abundance was observed along the assay. No preference of Scleroductus sp. for the gill arches was recorded, probably due to the low abundance of parasites on the gills. However, it seems probable that Scleroductus sp. may not exhibit the preference for the microhabitat, as already observed by Soylu et al. (2010) for Dactylogyrus crucifer Wagener, 1857 in Rutilus rutilus (Linnaeus, 1758) and lannacone and Alvarino (2012) for Mexicana sp. in Anisotremus scapularis (Tschudi, 1846).

Monogenean parasites exhibited preference for the first gill arches. Oliva and Luque (1998) found high abundance of the monogenean Microcotyle nemadactylus Dillon \& Hargis 1965 on the arch I and dorsal region of the wild fish Cheilodactylus variegatus Valenciennes, 1833, suggesting the enhancement of couple formation for reproduction. The preference for the gill arch I of Diclidophora merlangi (Kuhn In Nordmann, 1832) Krøyer, 1851 in whiting Gadus merlangus Linnaeus, 1758 proposed some host/parasite or parasite/parasite relationship (Arme \& Halton, 1972). Buchmann (1989) found arches I and II mostly parasitized by Pseudodactylogyrus bini (Kikuchi 1929) whereas P. anguillae (Yin \& Sproston, 1948) preferred the arches II and IV. The author suggested that the reason of this site selection was the size and development of the host Anguilla anguilla and not an interspecific factor. In Brazil, Jerônimo et al. (2013) have studied the microhabitat preference of two monogeneans, Mymarothecium boegeri Cohen \& Khon, 2005 and Anacanthorus penilabiatus Boeger, Husak \& Martins, 1995, on different hybrid fish. In the hybrid patinga (Piaractus mesopotamicus female $x P$. brachypomus male) preference for gill arch I were noted but no other preferences were found in other studied fish, the hybrids tambacu (Colossoma macropomum female $\times P$. mesopotamicus male) and surubim (Pseudoplatystoma corruscans). The authors suggested that the results could be related to the size of the arches and culture conditions, and the differences were not enough to support the hypothesis of microhabitat preference Aphanoblastella mastigatus showed preference for the arches I and II in the south american catfish, and no preference for gill sectors.. Rubio-Godoy and Tinsley (2002) and Rubio-Godoy (2008) have observed high number of the adult parasite Discocotyle sagittata in the first gill arches, and high number of larval stages on the arches III and IV of rainbow trout, suggesting that the larval stages reached the gill using the water flow in this region and then they would migrate to arches I and II to get space for new larvae. Acording to Buchmann (1989), the real reason for the preference for microhabitats, or niche restriction, is unknown, but chances for mating may be increased when microhabitats are narrow.

Based on the resutls of the present study we conclude that the abundance of parasites in the south american catfish is correlated to environmental conditions, supported by two evidences during the experiment. First, there was a turnover in the dominance of the species in relation to the environment of fish. Scleroductus sp. was dominant in the fish farm while $A$. mastigatus was dominant in the experiment tanks, showing the opportunistic feature of the species. Then, independently of the stocking density, A. mastigatus showed preference for regions more exposed to the external environment, and this could be related to a more favorable microhabitat for attachment, feeding and/or reproduction of the monogenean parasites. Future studies should investigate which factors are more important to determine this distribution pattern, and if it extends to other species of parasites and host.

\section{Acknowledgements}

The authors thank CNPq (National Council of Scientific and Technological Development) for financial support (CNPq 302493/20107) to M.L. Martins, for Master Science schoolarship to J.A. Debortoli, Dr. Natália Marchiori for parasite identification, Msc. Eduardo Luis Tavares Gonçalves for statistical analysis and Drs. Evoy Zaniboni Filho (Aquaculture Department, Federal University of Santa Catarina, SC, Brazil) and Cristiane F.M. Campos (State University of Mato Grosso do Sul, MS, Brazil) for critical review of the manuscript prior to submission.

\section{References}

Arme, C., Halton, D.W. (1972): Observations on the occurrence of Diclidophora merlangi (Trematoda: Monogenea) on the gills of whiting, Gadus merlangus. J. Fish Biol., 4(1): $27-32$. DOI: 10.1111/j.1095-8649.1972.tb05649.x 
Backer, T.G., Pante, E., Deburon, L. (2005): Co-occurrence of Naobranchia lizae (Copepoda) and Metamicrocotyla macracantha (Monogenea), gill parasites of the striped mullet Mugil cephalus. Parasitol. Res., 97(6): 515 - 520. DOI: 10.1007/s00436-005-1485-5

Baldisserotto, B., Gomes, L.C. (2010): (Orgs). Espécies nativas para a piscicultura no Brasil. $2^{\text {nd }}$ Edition, Santa Maria, Brazil, Editora UFSM, $470 \mathrm{pp}$.

BuCHMANN, K. (1989): Microhabitats of monogenean gill parasites on european eel (Anguilla anguilla). Folia Parasitol., 36(4): 321 - 329

Buchmann, K., Bresciani, J. (1997): Parasitic infections in pondreared rainbow trout Oncorhynchus mykiss in Denmark. Dis. Aquat. Org., 28(2): 125 - 138

Bush, A.O., LAFFERTY, K.D., LotZ, J.M., Shostak, W. (1997): Parasitology meets ecology on its own terms: Margolis et al. revisited. J. Parasitol., 83(4): 575 - 583

DzIKA, E. (1999): Microhabitats of Pseudodactylogyrus anguillae and P. Bini (Monogenea: Dactylogyridae) on the gills of large-size European eel Anguilla anguilla from Lake Gaj, Poland. Folia Parasitol., 46: $33-36$

EIRAS, J.C., TAKemoto, R.M. \& Pavanelli, G.C. (2006): Métodos de estudo e técnicas laboratoriais em parasitologia de peixes. $2^{\text {nd }}$ Edition, Maringá, Eduem, 199 pp.

El Hafidi, F., Berrada-Rkhami, O., Benazzou, T., Gabrion, C. (1998): Microhabitat distribution and coexistence of Microcotylidae (Monogenea) on the gills of the striped mullet Mugil cephalus: chance or competition? Parasitol. Res., 84(4): 315 - 320

GutiérRez, P.A., Martorelli, S.R. (1999): Niche preferences and spatial distribution of Monogenea on the gills of Pimelodus maculatus in Rio de la Plata (Argentina). Parasitology, 119(2): 183 - 188 Iannacone, J., Alvariño, L. (2012): Microecology of the monogenean Mexicana sp. on the gills of Anisotremus scapularis (Tschudi, 1846) (Osteichthyes, Haemulidae) of the marine coast of Lima, Peru. Neotrop. Helminthol., 6(2): $277-285$

Jeannette, T., Jacques, N., Félıx, B.B.C. (2010): Spatial distribution of Monogenean and Myxosporidian gill parasites of Barbus martorelli, Roman, 1971 (Teleostei: Cyprinid): The role of intrinsic factors. Afr. J. Agric. Res., 5(13): 1662 - 1669. DOI: $10.5897 /$ AJAR09.093

Jerônimo, G.T., Speck, G.M., Cechinel, M.M., GonçAlves, E.L.T., MARTINS, M.L. (2011a): Seasonal variation on the ectoparasitic communities of nile tilapia cultured in three regions in southern Brazil. Braz. J. Biol., 71(2): 365 - 373

Jerônimo, G.T., Martins, M.L., IshiKaWA, M.M., Ventura, A.S., TAVARES-DIAS, M. (2011b): Métodos para coleta de parasitos de peixes. Circular técnica Embrapa, 39, 1 - 6

Jerônimo, G.T., Gonçalves, E.L.T., Bampi, D., Paseto, A., Pádua, S.B., ISHIKAWA, M.M., MARTINS, M.L. (2013): Microhabitat of Monogenea and copepodids of Lernaea cyprinacea on the gills of four Brazilian freshwater fish. Neotrop. Helminthol., 7(1): $65-74$

Kadlec, D., Simková, A., Gelnar, M. (2003): The microhabitat distribution of two Dactylogyrus species parasitizing the gills of the barbell, Barbus barbus. J. Helminthol., 77: 317 - 325
Kohn, A., Cohen, S.C. (1998): South American Monogenea: list of species, hosts and geographical distribution. Int. J. Parasitol., 28(10): $1517-1554$

Kritsky, D.C., Boeger, W.A., Popazoglo, F. (1995): Neotropical Monogenoidea. 22. Variation in Scleroductus species (Gyrodactylidea, Gyrodactylidae) from siluriform fishes of Southeastern Brazil. J. Helminthol. Soc. Wash., 62: $53-56$

Kritsky, D.C., Boeger, W.A., Mendoza-Franco, E.F., Vianna, R.T. (2013): Neotropical Monogenoidea. 57. Revision and phylogenetic position of Scleroductus Jara \& Cone, 1989 (Gyrodactylidae), with description of new species from the Guatemalan chulin Rhamdia guatemalensis (Gunther) (Siluriformes: Heptapteridae) in Mexico and barred sorubim Pseudoplatystoma fasciatum (Linnaeus) (Siluriformes: Pimelodidae) in Brazil. Syst. Parasitol., 84(1): 1 - 15. DOI: 10.1007/s11230-012-9387-2

Marchiori, N., Tancredo, K., Roumbedakis, K., Gonçalves, E.L.T., Pereira Junior, J., Martins, M.L. (2013): New techniques for collecting eggs fro monogenean parasites. Exp. Parasitol., 134(2): $138-140$

Moraes, F.R., Martins, M.L. (2004): Condições predisponentes e principais enfermidades de teleósteos em piscicultura intensiva. In: Cyrino, J.E.P., Urbinati, E.C., Fracalossi, D.M., Castagnolli, N. (Eds): Tópicos especiais em piscicultura de água doce tropical intensiva. São Paulo, Brazil: Editora TecArt, pp. 343 - 383

Oliva, M.E., LUQUE, J.L. (1998): Distribution patterns of Microcotyle nemadactylus (Monogenea) on gill filaments of Cheilodactylus variegatus (Teleostei). Mem. Inst. Oswaldo Cruz, 93(4): 477 - 478 Paperna, I, Diamant, A. Overstreet, R.M. (1984): Monogenean infestations and mortality in wild and cultured Red Sea fishes. Helgol. Mar. Res., 37(1-4): $445-462$

Pouey, J.L.O.F., Piedras, S.R.N., Rocha, C.B., Tavares, R.A., SanTOS, J.D.M., BRITTO, A.C.P. (2011): Productive performance of silver catfish, Rhamdia quelen juveniles stocked at different densities. Ars Vet., 27(4): $241-245$

Raymond, K.M.N., Chapman, L.L., Lanciani, C.A. (2006): Host, macrohabitat, and microhabitat specificity in the gill parasite Afrodiplozoon polycotyleus (Monogenea). J. Parasitol., 92(6): 1211 - 1217 RoHDE, K. (1979): A critical evaluation of intrinsic and extrinsic factors responsible for niche restriction in parasites. Am. Nat., 114: $648-671$

Rubio-Godoy, M. (2008): Microhabitat selection of Discocotyle sagittata (Monogenea: Polyopisthocotylea) in farmed rainbow trout. Folia Parasitol., 55: 270 - 276

Rubio-Godoy, M., Tinsley, R.C. (2002): Trickle and single infection with Discocotyle sagittata (Monogenea: polyopisthocotylea): Effect of exposure mode on parasite abundance and development. Folia Parasitol., 49(4): 269 - 278

SilveiRA, F.S., Silva, F.M. (2011): Desempenho da pesca e da aquicultura. In: Epagri/Cepa: Síntese Anual da Agricultura de Santa Catarina - 2010-2011: 124 - 133. Retrieved September 3, 2013 from Cepa/Epagri website http://cepa.epagri.sc.gov.br/Publicacoes/Sintese_2012/sintese\%202012.pdf 
Soler-Jimenez, L.C. \& FaJer-Ávila, E.J. (2012): The microecology of Dactylogyrids (Monogenea: Dactylogyridae) on the gills of wild spotted rose snapper Lutjanus guttatus (Lutjanidae) from MazatIan Bay, Mexico. Folia Parasitol., 59(1): 53 - 58

Soylu, E., Ruzgar, B., Soylu, M. (2010): Seasonal dynamicas ans spatial distribution of Dactylogyrus crucifer Wagener, 1857 on the gills of roach (Rutilus rutilus L.) from Lake Sapanca, Turkey. Turk. J. Zool., 34: 393 - 398. DOI: 10.3906/zoo-0808-14

SuRIANO, D.M. (1986): El gênero Urocleidoides Mizelle y Price, 1964 (Monogenea: Ancyrocephalidae). Anatomia y posicion sistemática. Urocleidoides mastigatus sp. nov. y U. travassosi (Price, 1934) Molnar, Hanek y Fernando, 1974 parasitas de Rhamdia sapo (Valenciennes, 1840) Eigenmann y Eigenmann, 1888 y Pimelodella laticeps Eigenmann, 1917 (Pices: Siluriformes) de la laguna de Chascomus, Republica Argentina. Physis, 44: 73 - 80 Takemoto, R.M., Pavanelli, G.C., Lizama, M.A.P., Lacerda, A.C.F., Yamada, F.H., Moreira, L.H.A., CeschinI, T.L., Bellay, S. (2009): Di- versity of parasites of fish from the Upper Paraná River floodplain, Brazil. Braz. J. Biol., 69(2) Suppl.: $691-705$

Thatcher, V.E., Boeger, W.A., Vianna, R.T. (2006): Monogenoidea. In: Thatcher, V.E. (Ed) Aquatic Biodiversity in Latin America. $2^{\text {nd }}$ Edition, Bulgaria, Pensoft Publishers. pp. 42 - 110

ThONEY, D.A., HARGIS, W.J. (1991): Monogenea (platyhelminthes) as hazards for fish in confinement. Annu. Rev. Fish Dis., 1: 133 $-153$

Tu, X., Ling, F., Huang, A.G., Wang, G.X. (2015): An infection of Gyrodactylus kobayashii Hukuda, 1940 (Monogenea) associated with the mortality of goldfish (Carassius auratus) from central China. Parasitol. Res., 114(2): 737-745

Venancio, A.C.P., Aguiar, G.R., Lopes, P.S., Alves, D.R. (2010): Metazoan parasite of mandi-amarelo Pimelodus maculatus and of jundiá Rhamdia quelen (Osteichthyes: Siluriformes) of Paraíba do sul River, Volta Redonda, Rio de Janeiro. Brazilian Journal of Vet. Parasitol., 19(3): 157 - 163 